\title{
Characterization of the varicella-zoster virus gene 61 protein
}

\author{
David Stevenson, Kathryn L. Colman and Andrew J. Davison* \\ MRC Virology Unit, Institute of Virology, University of Glasgow, Church Street, Glasgow G11 5JR, U.K.
}

The protein predicted to be encoded by varicella-zoster virus (VZV) gene 61 exhibits limited amino acid sequence similarity to the herpes simplex virus type 1 nuclear phosphoprotein $\mathrm{Vmw} 110$, which functions as a transcriptional activator. The gene 61 protein was expressed in its entirety, or as an amino- or carboxyterminal fragment in Escherichia coli and vaccinia virus recombinants, and monospecific rabbit antisera were raised against an $E$. coli fusion between $\beta$-galactosidase and the majority of the gene 61 protein. Use of the antisera showed that the gene 61 protein is present in VZV-infected cell nuclei as a heterogeneous phospho- protein of $M_{\mathrm{r}} 62 \mathrm{~K}$ to $65 \mathrm{~K}$. Phosphorylation occurs in the amino- and, to a lesser extent, carboxy-terminal portions of the protein. The carboxy-terminal region directs transport of the protein to the nucleus, whereas the amino-terminal region, which contains a potential zinc-binding domain, is responsible for a punctate distribution. Preliminary mapping data indicated that gene 61 is transcribed as a $1.8 \mathrm{~kb}$ mRNA which initiates about $65 \mathrm{bp}$ upstream from the translation initiation codon, at a position located appropriately with respect to potential regulatory elements.

\section{Introduction}

The varicella-zoster virus (VZV) genome has been predicted to contain 67 distinct genes, 62 of which have counterparts in herpes simplex virus type 1 (HSV-1) based on amino acid sequence conservation (Davison \& Scott, 1986; McGeoch et al., 1988). Four of the five HSV1 immediate early genes have homologues in VZV : those encoding Vmw175, Vmw63, Vmw68 and Vmw110. Vmw175 is an essential protein with a central role in regulation of the HSV-1 transcriptional programme, and has been the subject of intense study (reviewed by Everett, 1987). The VZV gene 62 protein is highly similar (Davison \& Scott, 1985; McGeoch et al., 1986) and functionally analogous to Vmw175 (Felser et al., 1988; Disney \& Everett, 1990), and has been identified immunologically in infected cells (Felser et al., 1988; Forghani et al., 1990). Vmw63 is an essential protein which regulates later phases of HSV-1 transcription (reviewed by Sandri-Goldin, 1991). The VZV gene 4 protein shows limited similarity to Vmw63 (Davison \& Scott, 1986), and has been implicated in transcriptional regulation by transient expression studies (Inchauspe et al., 1989). The VZV gene 63 protein is the counterpart of Vmw68 (Davison \& Scott, 1985), which affects the host range of HSV-1 in cell culture (Sears et al., 1985).

Vmwl10 is translated from a spliced mRNA that is specified by a gene containing two introns in the proteinencoding region (Perry et al., 1986). The gene is not essential for virus growth in cell culture, but deletion mutants are severely impaired at low m.o.i. (Stow \& Stow, 1986). Vmw110 has been shown to activate transcription from several HSV-1 promoters, either alone or in conjuction with Vmw175 (reviewed by Everett, 1987). The protein is phosphorylated (Ackermann et al., 1984) and located in the nuclei of infected cells (Pereira et al., 1977). It has a predicted $M_{\mathrm{r}}$ of 78452 , but migrates with an apparent $M_{\mathrm{r}}$ of 110000 on SDSPAGE (Preston et al., 1978). The VZV gene 61 protein (henceforth referred to as 61) has a predicted $M_{\mathrm{r}}$ of 50913 (Davison \& Scott, 1986) and shows a marginal degree of similarity to Vmwl 10 in a cysteine-rich region which has been proposed to be a zinc-binding domain (Perry et al., 1986). This region is present at residues 116 to 156 of Vmwl10 and 19 to 57 of 61 , and is also a feature of several eukaryotic proteins (Freemont et al., 1991). Thus, it is quite possible that the two proteins share some functional aspects, but differ in others. Indeed, Inchauspe et al. (1989) have indicated that 61 may function in transcriptional regulation, but as a repressor rather than as an activator. In this paper, we have characterized the mRNA and protein products of gene 61 using the techniques of nucleic acid mapping, expression in heterologous systems and antibody studies.

\section{Methods}

Cells and viruses. Monolayers of CV-1 cells were grown in $5 \% \mathrm{CO}_{2}$ at $37^{\circ} \mathrm{C}$ in Dulbecco's modification of Eagle's medium supplemented with $4 \mathrm{~mm}$-glutamine, $100 \mathrm{units} / \mathrm{ml}$ penicillin, $100 \mu \mathrm{g} / \mathrm{ml}$ streptomycin 


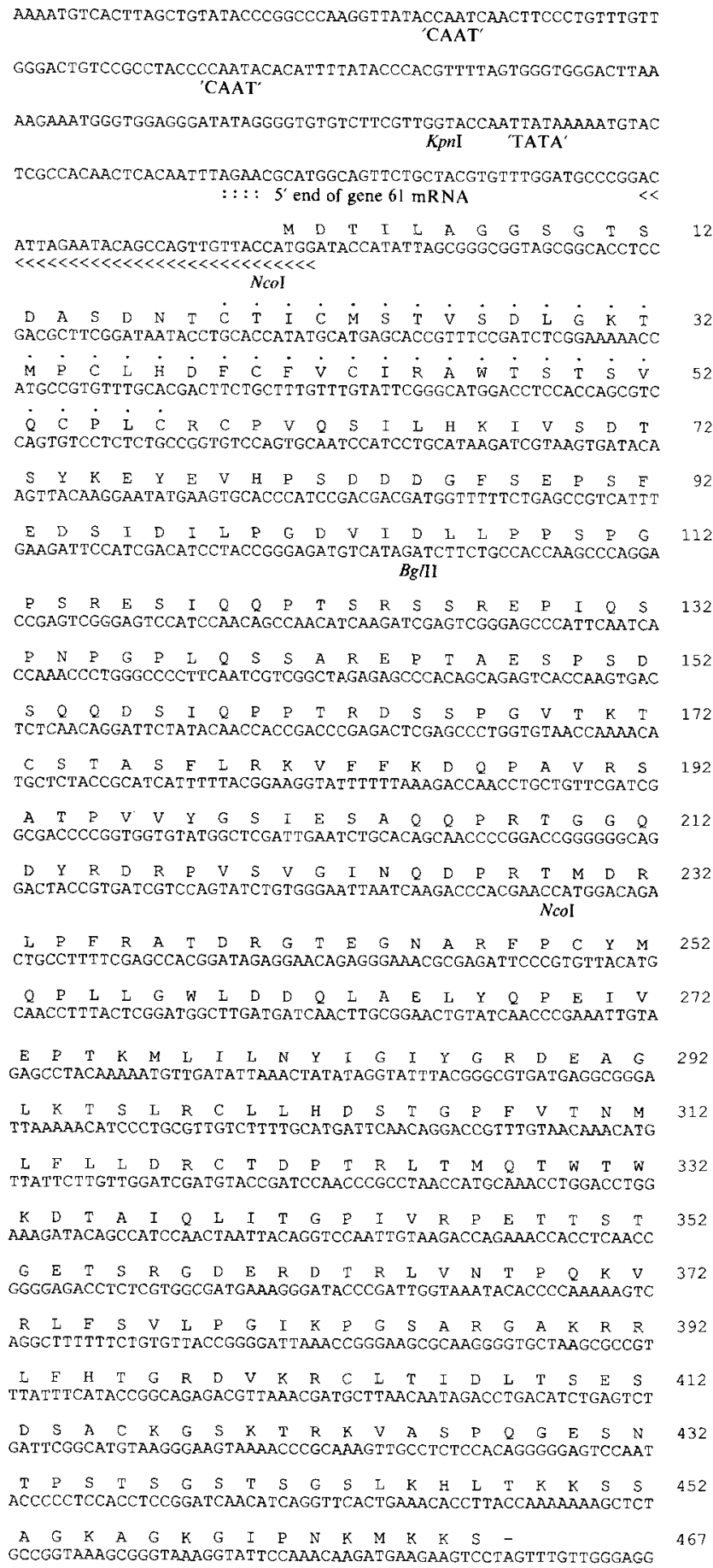

Fig. 1. DNA sequence of gene 61. The region between 102949 and 104749 in the complete VZV genome sequence (Davison \& Scott, 1986) has been inverted to orient the gene from left to right. Features of the DNA sequence are marked below the sequence, and those of the encoded protein above. Restriction endonuclease sites used in plasmid constructions are indicated; the AvaIII and HindIII sites mentioned in the text are 585 and $835 \mathrm{bp}$, respectively, downstream from the $3^{\prime}$ end of the sequence. The mapped $5^{\prime}$ end of gene $61 \mathrm{mRNA}$, and potential TATA and CAAT elements are indicated. The region complementary and $5 \%(\mathrm{v} / \mathrm{v})$ foetal calf serum (FCS). The VZV strain described by Dumas et al. (1981) was passaged in CV-1 cells by trypsinizing infected monolayers showing 20 to $50 \%$ c.p.e. and adding the cells at a ratio of $1: 5$ to $1: 1$ to uninfected subconfluent monolayers. Infected monolayers were incubated in $5 \% \mathrm{CO}_{2}$ at $37^{\circ} \mathrm{C}$ until 20 to $50 \%$ c.p.e. was observed (usually 1 to 2 days), and were then used for extraction of proteins or RNA, or for immunofluorescence. Vaccinia virus strain WR and recombinants derived therefrom were grown in $\mathrm{CV}-1$ cells. Proteins were extracted or immunofluorescence was performed 16 to $20 \mathrm{~h}$ after infection.

Construction of plasmids. Restriction endonuclease sites used for cloning are indicated on the DNA sequence shown in Fig. 1. VZV fragments were prepared from a plasmid containing VZV KpnI fragment i (Davison \& Scott, 1983).

pDK 1 was constructed for expression of residues 105 to 467 of 61 fused to the carboxy terminus of $\beta$-galactosidase by ligating a fragment extending from the $B g l I I$ site to the AvaIII site downstream from the $3^{\prime}$ end of the gene into the vector pUR290 (Rüther \& Müller-Hill, 1983) cut with BamHI and Pst I.

pDK 11 was constructed for expression of 61 in Escherichia coli by ligating a fragment extending from the $N c o I$ site encoding residue 1 to the HindIII site into the vector pKK240-11 (Amman \& Brosius, 1985) cut with Ncol and HindIII. pDK12, which expresses the carboxyterminal portion of 61 (61C) from residue 230, was obtained by digesting pDK 11 with $N c o$ I and religating. pDK 13 , which expresses the amino-terminal portion of $61(61 \mathrm{~N})$, was generated by inserting the NcoI fragment encoding residues 1 to 230 into the vector pKK233-2 (Pharmacia) cut with $\mathrm{Ncol}$. The construction encodes a protein consisting of the first 230 residues of 61 plus 19 additional vectorencoded residues at its carboxy terminus.

pMJ520 was constructed for expression of 61 in vaccinia virus by inserting VZV KpnI fragment i into the KpnI site of vector pMJ601 (Davison \& Moss, 1990). This vector contains the virus thymidine kinase gene into which has been inserted a cassette comprising a synthetic strong late promoter upstream from a multiple cloning site and $l a c Z$ under the control of an early promoter. Sequences between the HindIII site downstream from gene 61 and the HindIII site in the vector were removed by digesting with HindIII and religating. Sequences between the upstream $\mathrm{Sal}$ I site in the vector and the $\mathrm{NcoI}$ site encoding residue 1 were removed from the resulting plasmid by digesting with SalI and (partially with) NcoI, repairing the ends and religating. pMJ523 was constructed for expression of $61 \mathrm{C}$ in a similar manner by removal of sequences upstream from the internal $N c o$ I site. pMJ537 was constructed for expression of $61 \mathrm{~N}$ by removal of the sequence between the internal NcoI site and the HindIII site in pMJ520. This construct encodes a protein consisting of the first 230 residues of 61 plus 11 additional vector-encoded residues at its carboxy terminus.

Construction of vaccinia virus recombinants. Recombinants expressing $61,61 \mathrm{~N}$ and $61 \mathrm{C}$ at late times in infection were prepared as described by Davison \& Moss (1989). They are denoted VV61, VV61N and VV61C, respectively.

Preparation of rabbit antisera against 61 . The $\beta$-galactosidase fusion protein was extracted from bacteria containing pDK 1 following induction during the mid-log phase of growth by using $1 \mathrm{mM}$-IPTG for $2 \mathrm{~h}$ at $37^{\circ} \mathrm{C}$. The protein was purified using the method described by Steers et al. (1971), except that $p$-aminobenzyl 1-thio- $\beta$-D-galactopyranoside-agarose (Sigma) was employed for affinity chromatography;

to the oligodeoxyribonucleotide used for primer extension analysis is marked by arrowheads. The ATTAAA element close upstream from the region in which polyadenylation is predicted to occur is marked by asterisks. The amino acid sequence of 61 is shown above the DNA sequence with residue numbers to the right; the cysteine-rich domain which is also present in Vmwllo is marked by dots. 
$1.5 \mathrm{mg}$ protein was obtained per 1 of bacterial culture, but only about $10 \%$ was intact as judged by SDS-PAGE. This proportion was recovered even in the presence of several protease inhibitors.

Antisera against the purified fusion protein were prepared by Serotech Ltd., Oxford, U.K. Two sandy halflop rabbits were initially injected subcutaneously with $0.8 \mathrm{mg}$ fusion protein in $0.5 \mathrm{ml}$ emulsified with an equal volume of Freund's complete adjuvant. The rabbits were boosted on days 28,56 and 98 with $0.8 \mathrm{mg}$ fusion protein in $0.5 \mathrm{ml}$ emulsified with an equal volume of Freund's incomplete adjuvant. Final antisera were collected on day 125 .

Radiolabelling of infected cells. For labelling VZV proteins with ${ }^{35} \mathrm{~S}$, $5 \mathrm{~mm}$ Petri dishes of VZV-infected cells showing 20 to $50 \%$ c.p.e. were incubated at $37^{\circ} \mathrm{C}$ for $2 \mathrm{~h}$ in methionine-reduced medium containing $20 \%$ of the usual concentration of L-methionine and lacking FCS. The medium was then replaced with fresh methionine-reduced medium containing $100 \mu \mathrm{Ci} / \mathrm{ml} \mathrm{L}-\left[{ }^{35} \mathrm{~S}\right]$ methionine (SJ204; Amersham), and incubation was continued for 8 to $10 \mathrm{~h}$. For labelling with ${ }^{32} \mathbf{P}$, monolayers were incubated for $4 \mathrm{~h}$ in phosphate-free medium without FCS, and then with this medium supplemented with $100 \mu \mathrm{Ci} / \mathrm{ml}$ [32P]orthophosphate (PBS11; Amersham).

For labelling vaccinia virus proteins with ${ }^{35} \mathrm{~S}$, cells were infected with virus at a multiplicity of 10 and incubated at $37^{\circ} \mathrm{C}$ for $1 \mathrm{~h}$. The monolayers were then washed and overlaid with methionine-reduced medium containing $100 \mu \mathrm{Ci} / \mathrm{ml} \mathrm{L}-\left[{ }^{35} \mathrm{~S}\right]$ methionine and incubated at $37^{\circ} \mathrm{C}$ for 16 to $20 \mathrm{~h}$. For labelling with ${ }^{32} \mathrm{P}$, cells were incubated overnight in phosphate-free medium without FCS and then infected with virus at a multiplicity of 10 for $1 \mathrm{~h}$. The monolayers were washed

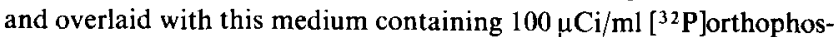
phate and incubated at $37^{\circ} \mathrm{C}$ for 16 to $20 \mathrm{~h}$.

Immunoblotting. Infected cell monolayers were rinsed twice with cold PBS (170 mu- NaCl, 3.4 mM-KCl, $10 \mathrm{~mm}-\mathrm{Na}_{2} \mathrm{HPO}_{4}, 1.8 \mathrm{~mm}-\mathrm{KH}_{2} \mathrm{PO}_{4}$ $\mathrm{pH} \mathrm{7.2)} \mathrm{and} \mathrm{scraped} \mathrm{into} 1 \mathrm{ml}$ PBS. Cells were pelleted by brief centrifugation in a benchtop microfuge at $4{ }^{\circ} \mathrm{C}$, resuspended in $0.25 \mathrm{ml}$ PBS, heated at $100^{\circ} \mathrm{C}$ for 5 to $10 \mathrm{~min}$ with $0.25 \mathrm{ml}$ boiling mix $(80 \mathrm{~mm}$ Tris- $\mathrm{HCl} \mathrm{pH} 6.8,2 \% \mathrm{w} / \mathrm{v}$ SDS, $0.1 \mathrm{~m} \mathrm{DTT}, 10 \% \mathrm{v} / \mathrm{v}$ glycerol, $0.5 \mathrm{~mm}$ bromophenol blue) and stored at $-20^{\circ} \mathrm{C}$. Bacterial extracts were prepared by inoculating $1 \mathrm{ml} \mathrm{L}$ broth with $50 \mu \mathrm{l}$ of an overnight culture of the appropriate clone, incubating at $37^{\circ} \mathrm{C}$ for $2 \mathrm{~h}$ and inducing with $1 \mathrm{mM}$-IPTG at $37^{\circ} \mathrm{C}$ for $2 \mathrm{~h}$. Bacterial pellets were washed with PBS and lysed as described above.

Immunoblotting was performed as described by Frame et al. (1987), using antisera at a dilution of $1: 10$. Immune complexes were detected by binding to ${ }^{125}$ I-labelled Protein A.

Immunoprecipitation. Infected cell monolayers were washed twice with cold PBS and scraped into $0.5 \mathrm{ml} 0.1 \mathrm{M}-\mathrm{Tris}-\mathrm{HCl} \mathrm{pH} 8,10 \%(\mathrm{v} / \mathrm{v})$ glycerol, $0.5 \%(\mathrm{v} / \mathrm{v})$ NP40, $0.5 \%(\mathrm{w} / \mathrm{v})$ sodium deoxycholate and 0.2 mM-PMSF. Lysed cells were incubated on ice for $1 \mathrm{~h}$ and then centrifuged for $10 \mathrm{~min}$ in a bench microfuge at $4{ }^{\circ} \mathrm{C}$ to pellet cell debris. The supernatant was stored at $-20^{\circ} \mathrm{C}$. Immunoprecipitation was carried out as described by Murphy et al. (1989).

Fractionation of cells infected with vaccinia virus recombinants. Infected cells were separated into cytoplasmic and nuclear fractions, and nuclei were extracted sequentially with buffers containing increasing concentrations of $\mathrm{NaCl}$ by a modification of the method described by Piette $e t$ al. (1985). Infected cell monolayers were washed with cold PBS and scraped into $1 \mathrm{ml}$ PBS. Cells were pelleted by centrifugation at 2000 r.p.m. in a Beckman GPR centrifuge, resuspended in $1 \mathrm{ml}$ buffer $A$ (10 mM-HEPES-KOH pH 8.0, $50 \mathrm{~mm}-\mathrm{NaCl}, 0.5 \mathrm{~m}$-sucrose, $1 \mathrm{~mm}$ EDTA, $0.5 \%$ v/v Triton X-100, $7 \mathrm{~mm}-2$-mercaptoethanol, $1 \mathrm{~mm}-$ PMSF) and lysed by Dounce homogenization. Nuclei were pelleted by centrifugation at 3000 r.p.m. for $10 \mathrm{~min}$ at $4^{\circ} \mathrm{C}$, washed twice with $1 \mathrm{ml}$ buffer $\mathrm{A}$, resuspended in $333 \mu \mathrm{l}$ buffer $\mathrm{B}$ (10 mM-HEPES-KOH
pH 8.0, $100 \mathrm{~mm}-\mathrm{NaCl}, 25 \% \mathrm{v} / \mathrm{v}$ glycerol, $0.1 \mathrm{~mm}$-EDTA, $7 \mathrm{~mm}-2-$ mercaptoethanol, $1 \mathrm{mM}$-PMSF) and placed in a rotary mixer for $15 \mathrm{~min}$ at $4^{\circ} \mathrm{C}$. The nuclear suspension was centrifuged at 3000 r.p.m. for $10 \mathrm{~min}$ at $4{ }^{\circ} \mathrm{C}$ and the pellet was resuspended in $333 \mu \mathrm{l}$ buffer $\mathrm{C}$ (as buffer $\mathrm{B}$, except that the $\mathrm{NaCl}$ concentration was $400 \mathrm{mM}$ ). After rotary mixing for $30 \mathrm{~min}$ at $4{ }^{\circ} \mathrm{C}$, the suspension was centrifuged at 5000 r.p.m. for $10 \mathrm{~min}$ at $4{ }^{\circ} \mathrm{C}$. The pellet was resuspended in buffer $\mathrm{D}$ (as buffer $\mathrm{B}$, except that the $\mathrm{NaCl}$ concentration was $2 \mathrm{M}$ ), sonicated for $10 \mathrm{~s}$ at $0{ }^{\circ} \mathrm{C}$ in a Heat Systems-Ultrasonics W-380 cup-horn sonicator and centrifuged in a bench microfuge at 13000 r.p.m. for $20 \mathrm{~min}$ at $4^{\circ} \mathrm{C}$. The pellet was washed twice with $1 \mathrm{ml}$ buffer B. Supernatants from each step were dialysed overnight at $4{ }^{\circ} \mathrm{C}$ against $500 \mathrm{ml}$ buffer $B$ with one change of buffer. Aliquots were heated with boiling mix for SDS-PAGE, and the remainder of each fraction was stored at $-20^{\circ} \mathrm{C}$.

Immunofluorescence. Cell monolayers were fixed and permeabilized as described by Randall \& Dinwoodie (1986). Incubation with antisera and fluorescein isothiocyanate-conjugated goat anti-rabbit antibody (Sigma) was carried out at dilutions of $1: 20$ and 1:80, respectively. Slides were viewed using a Zeiss Axioplan Universal microscope and photographed using a Zeiss MC100 camera with Kodak Tri-X-Pan 400 film.

Dephosphorylation of proteins in vitro. Dephosphorylation was performed as described by Smith et al. (1989). Briefly, $30 \mu \mathrm{l}$ cell extract was mixed with $30 \mu \mathrm{l} 0.2 \mathrm{M}$-Tris- $\mathrm{HCl} \mathrm{pH} 8 \cdot 0,10 \mu \mathrm{M}-\mathrm{ZnCl}_{2}$ and incubated at $30^{\circ} \mathrm{C}$ for $16 \mathrm{~h}$ in the presence or absence of $1 \mathrm{U}$ calf intestinal phosphatase. Aliquots were subjected to immunoprecipitation or immunoblotting.

Gel electrophoresis of proteins. SDS-PAGE was conducted using $9 \%$ (w/v) polyacrylamide gels cross-linked with $1: 37.5(\mathrm{w} / \mathrm{w}) N, N^{\prime}-$ methylenebisacrylamide. Gels from immunoprecipitation experiments were fixed in $10 \%(\mathrm{v} / \mathrm{v})$ acetic acid, $50 \%(\mathrm{v} / \mathrm{v})$ methanol, treated with En ${ }^{3}$ Hance (New England Nuclear), dried and autoradiographed using Kodak XS-6 film with a Dupont Cronex Lightning Plus intensifying screen at $-70{ }^{\circ} \mathrm{C}$.

Analysis of RNA. Total cellular RNA was isolated from uninfected or VZV-infected cells using the acid guanidinium thiocyanate-phenolchloroform extraction procedure described by Chomczynski \& Sacchi (1987). Northern blotting of RNA electrophoresed on formaldehydeagarose denaturing gels was carried out as described by Sambrook $e t$ al. (1989). Nitrocellulose sheets were probed with plasmids radiolabelled by nick translation. The $5^{\prime}$ end of gene $61 \mathrm{mRNA}$ was mapped by primer extension (Sambrook et al., 1989) of the complementary $5^{\prime}{ }^{32} \mathrm{P}$ labelled oligodeoxyribonucleotide indicated in Fig. 1.

\section{Results}

\section{Expression of 61 by $V Z V$ and in heterologous systems}

Antisera obtained from rabbits immunized with the major part of 61 fused to $\beta$-galactosidase were assayed by immunoblotting of 61 expressed in $E$. coli and in CV-1 cells infected with VZV or the vaccinia virus recombinant VV61. Results obtained using antiserum obtained at day 125 from one rabbit are shown in Fig. 2. Immune serum from the other rabbit also reacted with 61 , but preimmune sera from either rabbit did not (data not shown). The anti-61 serum did not react strongly with proteins in uninduced $E$. coli containing pKK240-11 (lane 1), but did recognize the high $M_{\mathrm{r}} \beta$-galactosidase 


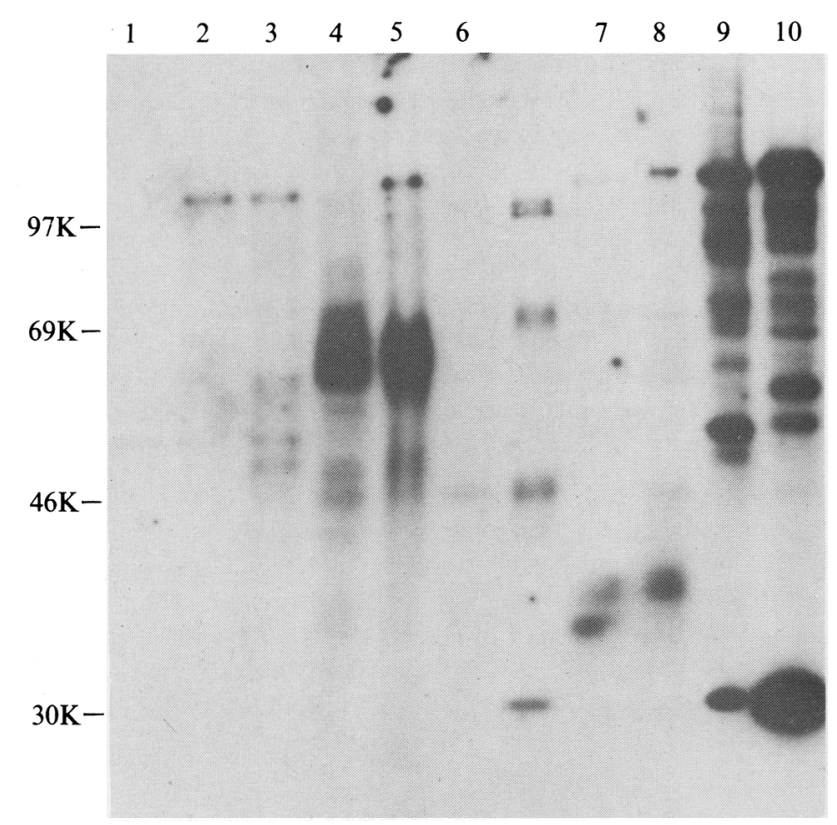

Fig. 2. Autoradiograph showing results of immunoblotting gene 61 proteins with the anti-61 serum. Lane 1, uninduced $E$. coli containing pKK240-11 ; lane 2, IPTG-induced $E$. coli containing pKK240-11; lane 3 , induced $E$. coli containing pDK11 (expressing 61); lane 4, VZVinfected cells; lane 5, VV61-infected cells; lane 6, uninfected CV-1 cells; lane 7, induced $E$. coli containing pDK 12 (expressing $61 \mathrm{~N}$ ); lane 8 , VV61N-infected cells; lane 9, induced $E$. coli containing pDK13 (expressing 61C); lane 10, VV61C-infected cells. Lanes contained various amounts of extract. $M_{\mathrm{r}}$ markers are shown to the left and in the unlabelled lane.

fragment synthesized in IPTG-induced E. coli containing pKK240-11 (lane 2). When pDK11 was induced, several additional proteins, presumably representing gene 61 translation products, were detected; the largest had an $M_{\mathrm{r}}$ of 62000 (lane 3). In contrast, the antiserum reacted with a range of proteins present in cells infected with VZV or VV61 (lanes 4 and 5) which were absent from uninfected cells (lane 6). The apparently lower $M_{\mathrm{r}}$ of 61 expressed by VV61 was due to an imperfection in the gel; other experiments indicated comparable mobilities (data not shown). The most abundant forms of 61 had $M_{\mathrm{r}} \mathrm{s}$ of $62 \mathrm{~K}$ to $65 \mathrm{~K}$, but species with $M_{\mathrm{r}} \mathrm{s}$ in excess of 70000 were evident. The antiserum also recognized $\beta$-galactosidase in VV61-infected cells, visible as a high $M_{\mathrm{r}}$ protein in lane 5 because the recombinant contains lac $Z$ in addition to gene 61 . The largest 61 species produced in $E$. coli approximately corresponded in size to the smallest produced in CV-1 cells. Smaller E. coli proteins may have resulted from proteolysis. These results indicate that when synthesized in eukaryotic cells 61 may undergo post-translational modifications which increase its apparent $M_{\mathrm{r}}$ and generate size heterogeneity.

Fig. 2 also shows the results of expressing the aminoand carboxy-terminal portions of $61(61 \mathrm{~N}$ and $61 \mathrm{C})$ in $E$. (a)
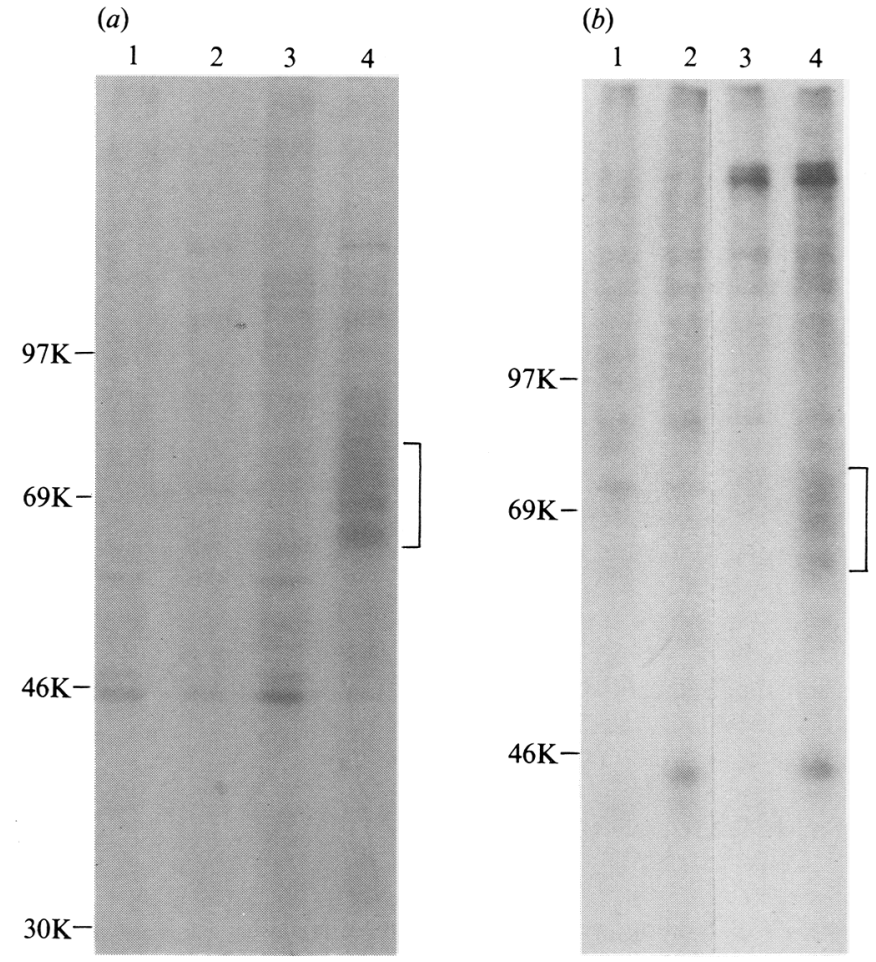

Fig. 3. Autoradiographs showing results of immunoprecipitation of VZV-infected cell extracts labelled with $(a){ }^{35} \mathrm{~S}$ or $(b){ }^{32} \mathrm{P}$. Lanes 1 and 3 contain uninfected cell extracts, and lanes 2 and 4 contain VZVinfected cell extracts. Lanes 1 and 2 represent immunoprecipitation using (a) preimmune serum or $(b)$ non-specific rabbit serum, and lanes 3 and 4 immunoprecipitation using anti-61 serum. The heterogeneous set of proteins precipitated by anti-61 serum is indicated to the right of each panel. $M_{\mathrm{r}}$ markers are shown to the left of each panel.

coli and vaccinia virus recombinants. $E$. coli $61 \mathrm{~N}$ was synthesized as a single species with an $M_{\mathrm{r}}$ of 36000 (lane 7; the artefactual bands with slightly higher and lower $M_{\mathrm{r}} \mathrm{s}$ were not detected in other experiments), whereas proteins produced by $\mathrm{VV} 61 \mathrm{~N}$ had $M_{\mathrm{r}} \mathrm{s}$ of $36 \mathrm{~K}$ to $39 \mathrm{~K}$ (lane 8). However, direct comparison of size was complicated by the fact that the E. coli and VV61N proteins differ at their carboxy termini; the former is eight amino acid residues longer. There was no difference in mobility between $61 \mathrm{C}$ produced in $E$. coli or by VV61C (lanes 9 and 10). The proteins of higher $M_{\mathrm{r}}$ in these lanes are related to $\beta$-galactosidase and its breakdown products, and are particularly noticeable owing to the amount of extract loaded.

\section{Phosphorylation of 61 in vivo}

Since Vmw110 is a phosphoprotein and expression of 61 in heterologous systems suggested that it undergoes posttranslational modification in eukaryotic cells, immunoprecipitation of cell extracts labelled with ${ }^{35} \mathrm{~S}$ or ${ }^{32} \mathrm{P}$ was performed. Immunoprecipitation of extracts from ${ }^{35} \mathrm{~S}-$ 
(a)

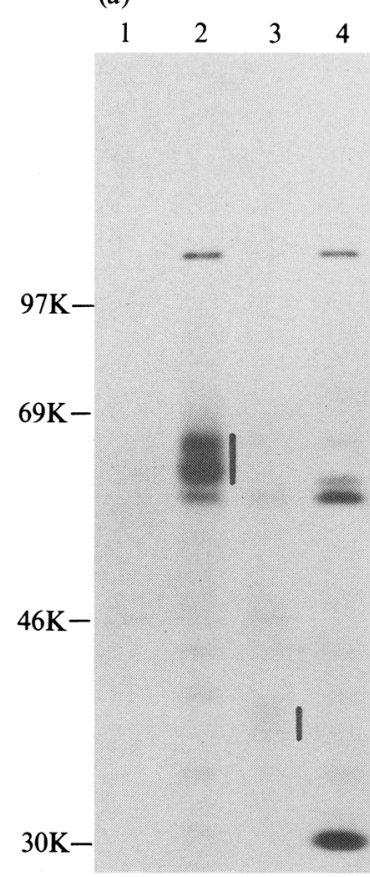

(b)

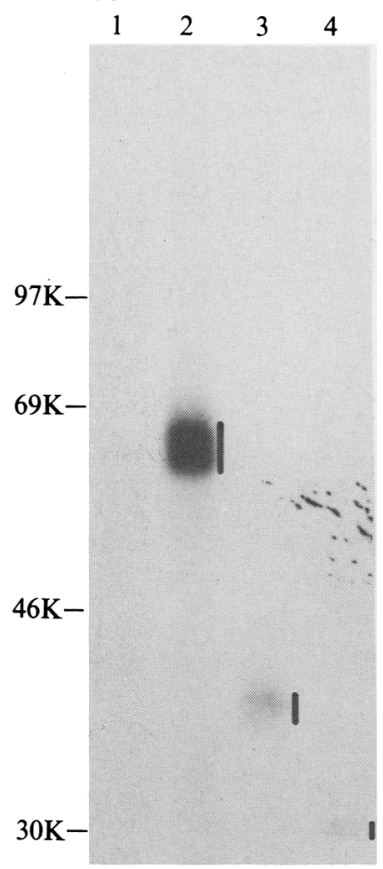

Fig. 4. Autoradiographs showing results of immunoprecipitation with the anti-61 serum of extracts from cells infected with vaccinia virus recombinants and labelled with $(a){ }^{35} \mathrm{~S}$ or $(b){ }^{32} \mathrm{P}$. Lanes 1 , uninfected cells; lanes 2, VV61-infected cells; lanes 3, VV61 N-infected cells; lanes 4, VV61C-infected cells. Specifically precipitated proteins related to 61 are indicated by vertical lines to the right of each lane. $M_{\mathrm{r}}$ markers are shown to the left of each panel.

labelled VZV-infected cells showed recognition of a heterogeneous set of proteins by the anti-61 serum. The most abundant migrated with $M_{\mathrm{r}} \mathrm{s}$ in the region of $62 \mathrm{~K}$ to $65 \mathrm{~K}$, but larger species were again detected (Fig. $3 a$, lane 4). Proteins of similar size were precipitated from ${ }^{32} \mathrm{P}$ labelled extracts (Fig. $3 b$, lane 4 ), but not by a nonspecific rabbit antiserum (lane 2). These results indicate that 61 is present as a phosphoprotein in VZV-infected cells. Rather weak reactions were observed consistently, and presumably reflect low levels of 61 present in the extracts or low affinity of the antiserum in immunoprecipitation reactions.

${ }^{35} \mathrm{~S}$-labelled proteins were also specifically precipitated from cells infected with VV61, VV61N and $\mathrm{VV} 61 \mathrm{C}$, and these corresponded in $M_{\mathrm{r}}$ to proteins detected by immunoblotting $(62 \mathrm{~K}$ to $65 \mathrm{~K}, 36 \mathrm{~K}$ to $39 \mathrm{~K}$ and $30 \mathrm{~K}$, respectively; Fig. $4 a$, lanes 2 to 4 ). Each of these proteins was shown to be phosphorylated (Fig. $4 b$, lanes 2 to 4 ), indicating that phosphate groups are present in at least two regions of 61 . The amount of extract loaded for different recombinants cannot be considered to be equivalent, because different proportions of cells were detached from monolayers during infection. It appears, for example, that more cells were lost after infection with VV61N. Nevertheless, because samples of the same

(a)

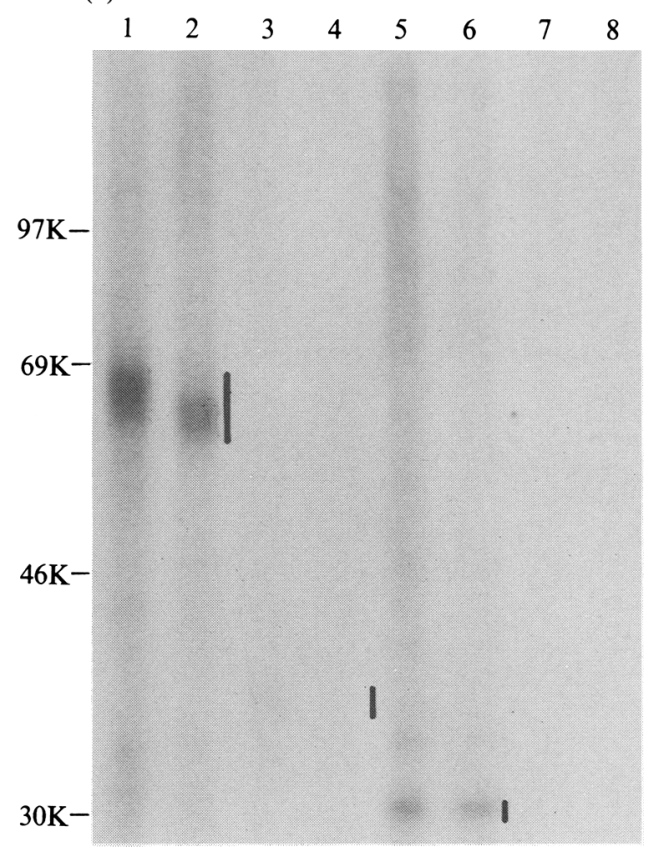

(b)

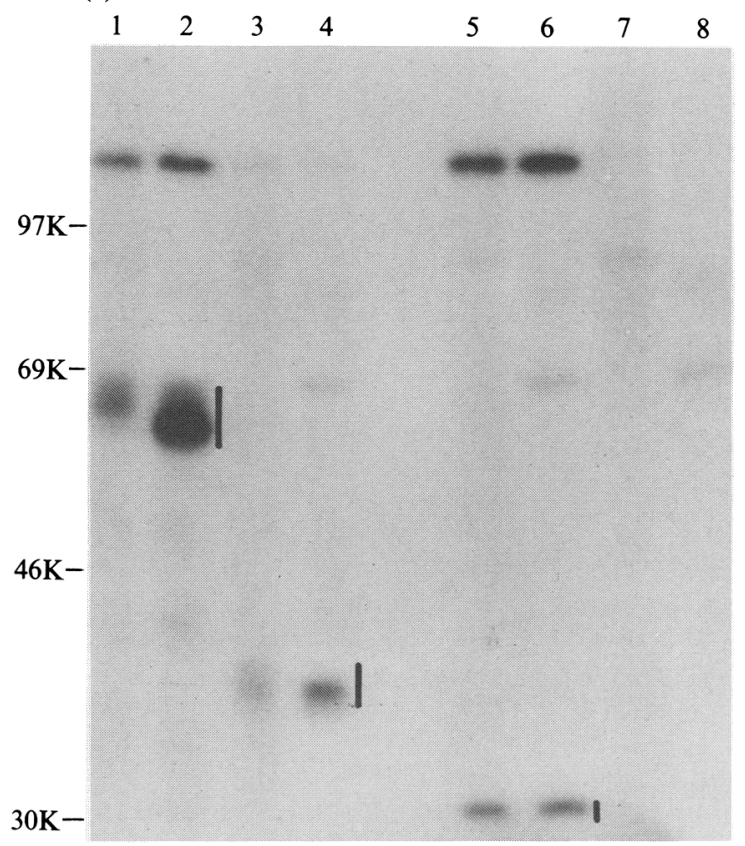

Fig. 5. Autoradiographs showing the result of treating extracts of cells infected by vaccinia virus recombinants with calf intestinal phosphatase. (a) Immunoprecipitation of ${ }^{32}$ P-labelled extracts; $(b)$ immunoblotting of ${ }^{35} \mathrm{~S}$-labelled extracts with anti-61 serum. Lanes 1 and 2 , VV61-infected cells; lanes 3 and 4, VV61 N-infected cells; lanes 5 and 6, VV61C-infected cells; lanes 7 and 8, uninfected cells. Samples in lanes 2, 4, 6 and 8 were treated with calf intestinal phosphatase. Specifically recognized proteins are indicated to the right of each pair of lanes. $M_{\mathrm{r}}$ markers are shown to the left of each panel. 


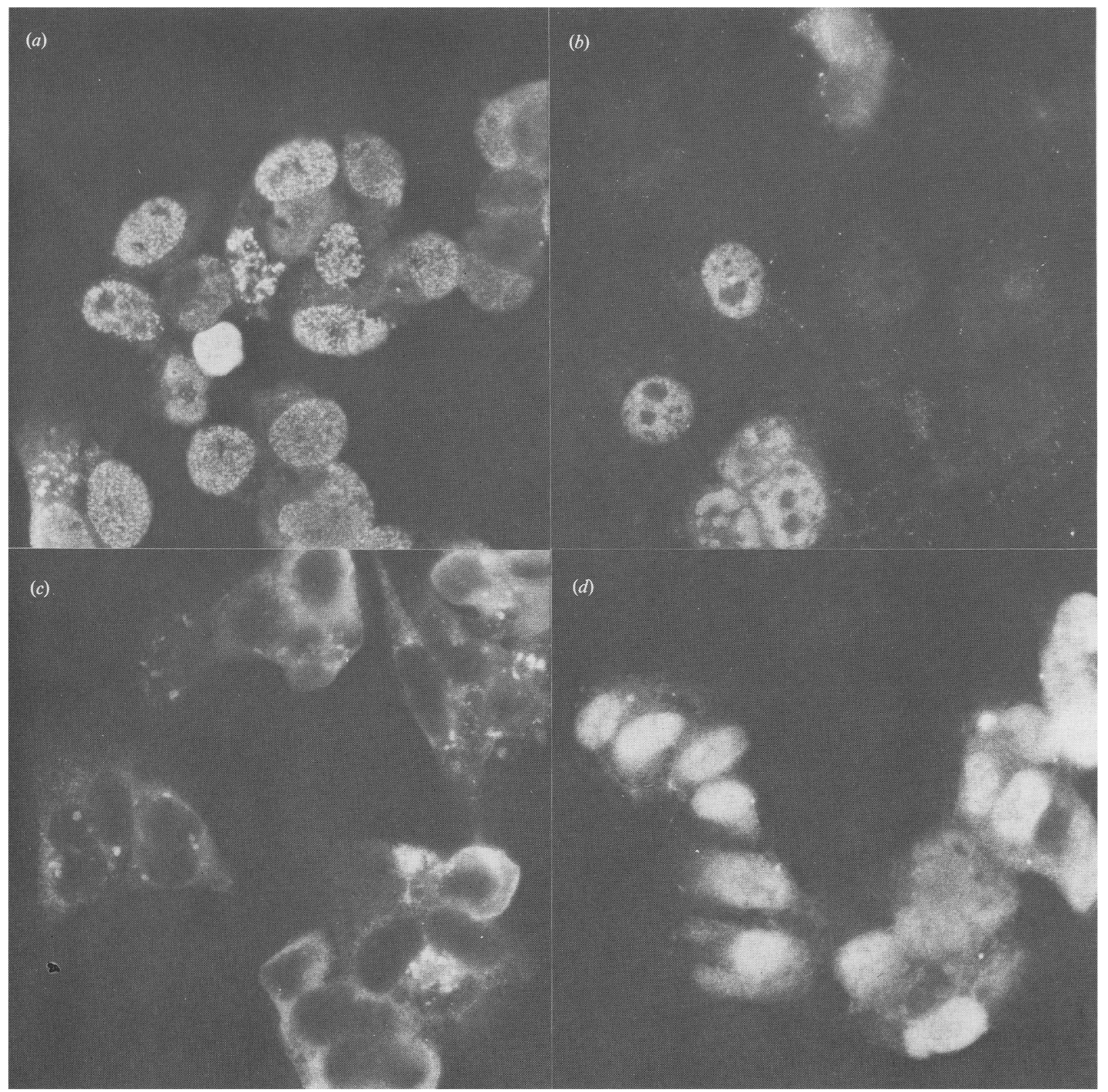

Fig. 6. Photomicrographs showing immunofluorescence produced by labelling with anti-61 serum. (a) VV61-infected cells; $(b)$ VZVinfected cells; (c) VV61N-infected cells; (d) VV61C-infected cells.

volume were loaded on corresponding lanes in Fig. 4(a) and $(b)$, the relative intensities of the ${ }^{32} \mathrm{P}$ - and ${ }^{35} \mathrm{~S}$ labelled proteins indicate that $61 \mathrm{~N}$ is much more highly phosphorylated than $61 \mathrm{C}$. Therefore, it is likely that 61 is phosphorylated at multiple sites, the majority in the amino-terminal region.

\section{Dephosphorylation of 61 in vitro}

To determine whether phosphorylation contributes to the greater $M_{\mathrm{r}}$ of 61 expressed in eukaryotic cells and to its size heterogeneity, ${ }^{35} \mathrm{~S}$ - and ${ }^{32} \mathrm{P}$-labelled extracts from cells infected with vaccinia virus recombinants were dephosphorylated using calf intestinal phosphatase and analysed by immunoprecipitation (Fig. $5 a$ ) and immunoblotting (Fig. $5 b$ ). The $M_{\mathrm{r}}$ of 61 was reduced by dephosphorylation, although only a proportion of phosphate groups were removed and a degree of size heterogeneity was retained (Fig. 5a, lanes 1 and 2). In this experiment only a small amount of phosphorylated $61 \mathrm{~N}$ was detected before treatment, and the label was not detected after dephosphorylation (Fig. $5 a$, lanes 3 and 4). 

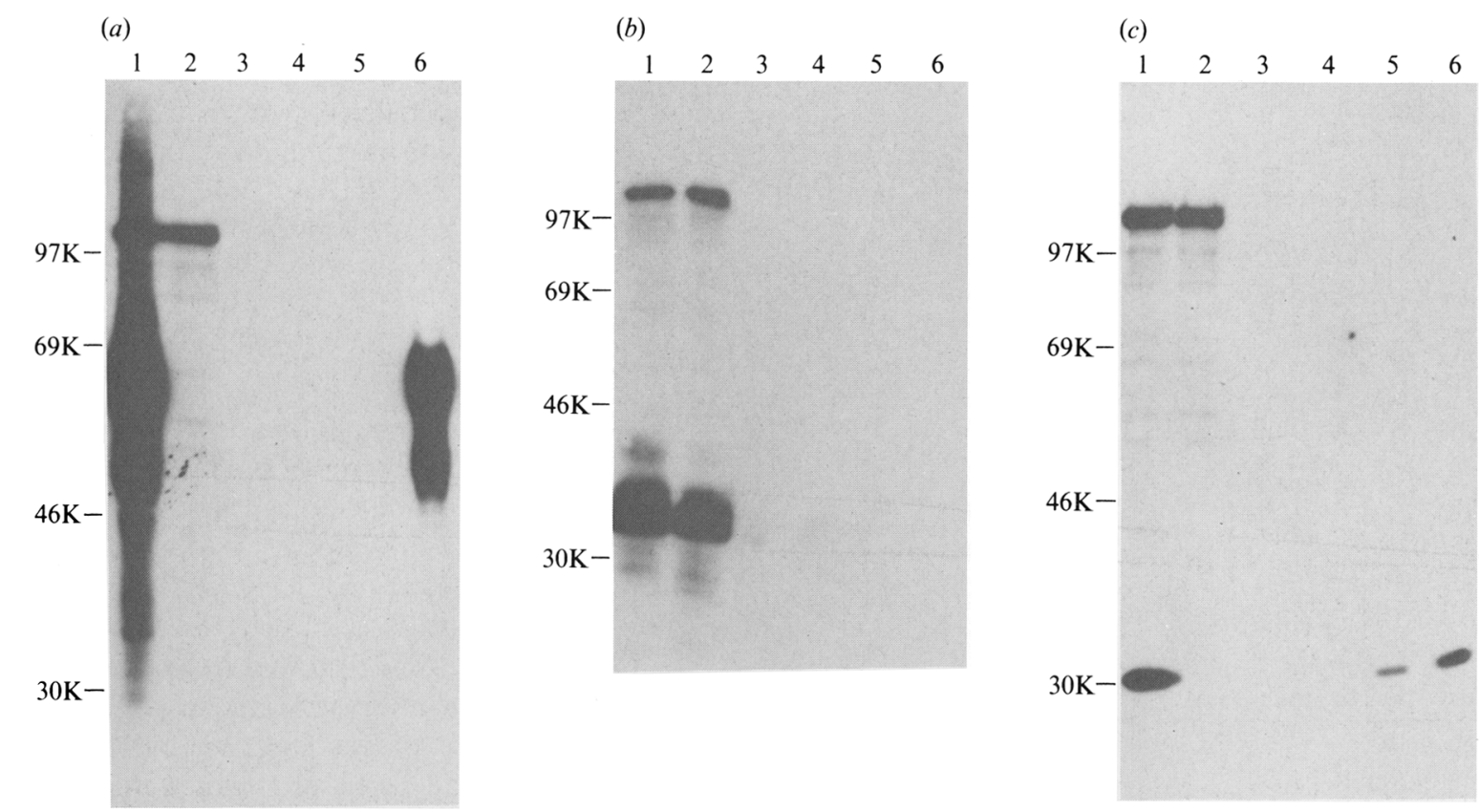

Fig. 7. Autoradiographs showing results of immunoblotting with anti-61 serum of subcellular fractions of cells infected with $(a)$ VV61, (b) VV61 N and (c) VV61C. Lanes 1, whole cell extract; lanes 2, cytoplasmic fraction; nuclear proteins eluted with $100 \mathrm{mM}$ - (lanes 3), $400 \mathrm{~mm}$ - (lanes 4) and $2 \mathrm{M}-\mathrm{NaCl}$ (lanes 5); lanes 6, final nuclear pellet. $M_{\mathrm{r}}$ markers are shown to the left of each panel.

In contrast, phosphate groups on $61 \mathrm{C}$ were refractory, and the $M_{\mathrm{r}}$ was not altered (Fig. $5 a$, lanes 5 and 6). These results were confirmed by immunoblotting experiments, in which the $M_{\mathrm{r}} \mathrm{s}$ of major forms of $61,61 \mathrm{~N}$ and $61 \mathrm{C}$ after treatment with phosphatase were 62000,36000 and 30000 , respectively (Fig. $5 b$, lanes $2,4,6$ ). The proportion of $61 \mathrm{~N}$ in the higher $M_{\mathrm{r}}$ form $(39000)$ prior to dephosphorylation was greater in most other experiments (data not shown). These results show that the size heterogeneity of 61 is due to phosphorylation in the amino-terminal region, and that phosphoamino acids in this region are more vulnerable to calf intestinal phosphatase than those in the carboxy-terminal region.

The stronger reaction of the antiserum in immunoblots with dephosphorylated forms of 61 and $61 \mathrm{~N}$ was noted in several experiments. This probably reflects the fact that the antisera were raised against a portion of 61 expressed in $E$. coli, in which 61 does not undergo processing similar to that which occurs in eukaryotic cells. Thus, phosphorylation of 61 in eukaryotic cells may mask antigenic sites present on the $E$. coli protein. Also, since antibodies are directed against only a portion of 61 , it is likely that the region from residues 105 to 230 contains at least some of the amino acids whose phosphorylation results in the observed increase in $M_{\mathrm{r}}$.

\section{Subcellular localization of 61}

Immunofluorescence experiments showed that 61 is located in a punctate pattern in the nuclei of cells infected with VV61 (Fig. 6a). In VZV-infected cells, 61 was also detected in the nuclei, but in a more diffuse pattern (Fig. 6b). 61 is apparently absent from nucleoli in VZV-infected cells, and this is probably also the case for VV61-infected cells. Fig. 6(b) also shows several uninfected CV-1 cells. $61 \mathrm{~N}$ was detected in the cytoplasm (Fig. 6c), whereas $61 \mathrm{C}$ was located in a diffuse pattern in the nuclei (Fig. $6 d$ ). Since the anti-61 serum was raised against a $\beta$-galactosidase fusion protein, expression of $\beta$ galactosidase by the vaccinia virus recombinants presented a potential problem in these experiments. However, the levels of interference by antibodies against $\beta$-galactosidase were shown to be minimal by the use of antisera prepared against other $\beta$-galactosidase fusion proteins and vaccinia virus recombinants expressing $\beta$ galactosidase, but not 61 (data not shown).

The results of immunofluorescence were confirmed by subcellular fractionation experiments (Fig. 7). 61 was detected in the nuclei of cells infected with VV61, and was not eluted by sonication in the presence of $2 \mathrm{M}-\mathrm{NaCl}$ (Fig. 7a). 61N was detected in the cytoplasmic fraction (Fig. 7 b), but $61 \mathrm{C}$ was largely resistant to extraction from nuclei, only a minor proportion being solubilized in $2 \mathrm{M}^{-}$ $\mathrm{NaCl}$ (Fig. $7 c$ ). In each case, $\beta$-galactosidase expressed by the recombinants was present in the cytoplasm. It is possible that the relative insolubility of nuclear 61 and 61C results from high levels of expression by the vaccinia virus recombinants. Attempts to detect 61 in fractionated VZV-infected cells were unsuccessful, presumably owing to low levels of antigen. 


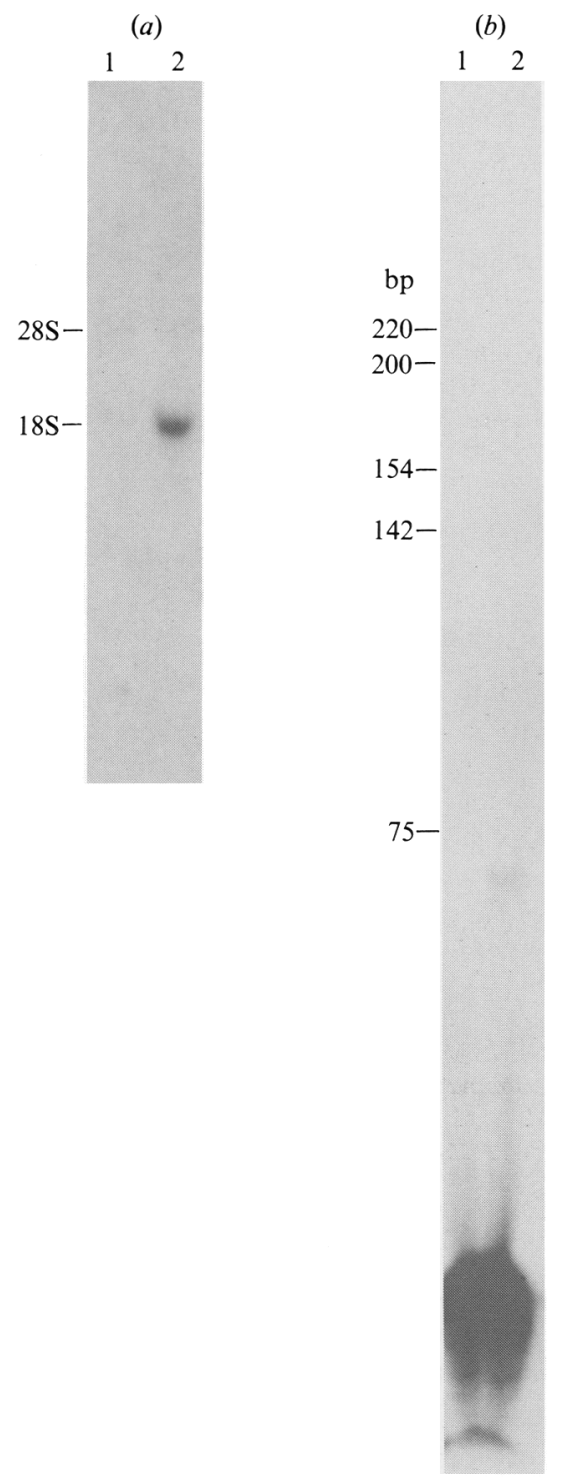

Fig. 8. Autoradiographs showing mapping of gene 61 mRNA. (a) Northern blot of whole cellular RNA probed with pDK1. (b) Primer extension analysis of whole cellular RNA using the oligodeoxyribonucleotide shown in Fig. 1. Lanes 1, uninfected cell RNA; lanes 2, VZV-infected cell RNA. Positions of $28 \mathrm{~S}$ and $18 \mathrm{~S}$ rRNAs, and of ssDNA marker molecules (nucleotides) are shown to the left of $(a)$ and (b), respectively.

\section{Preliminary mapping of the gene $61 \mathrm{mRNA}$}

A Northern blot of total cellular RNA extracted from uninfected or VZV-infected cells was probed with pDK1 (Fig. 8a). A single VZV-specific RNA species of approximately $1.8 \mathrm{~kb}$ was detected (lane 2 ). It was not detected when the parent plasmid, pUR290, was used as probe (data not shown). Primer extension of an oligodeoxyribonucleotide complementary to the proposed gene $61 \mathrm{mRNA}$ (see Fig. 1) generated a product of approximately 70 nucleotides specifically from VZVinfected cell RNA (Fig. 8b, lane 2). Thus, the proposed $5^{\prime}$ end of gene $61 \mathrm{mRNA}$ is located about $65 \mathrm{bp}$ upstream from the translation initiation site (see Fig. 1). The size of the transcript is consistent with polyadenylation in the region predicted from sequence considerations, close downstream from the ATTAAA element shown in Fig. 1 (Davison \& Scott, 1986).

\section{Discussion}

The existence of gene 61 was predicted from DNA sequence data on the basis of the presence of a leftwardoriented open reading frame containing 467 codons in the genome (Davison \& Scott, 1986). We have confirmed the presence of this gene by showing that it is transcribed and translated in VZV-infected cells. We have also characterized the gene 61 protein expressed by VZV and vaccinia virus recombinants and in $E$. coli.

Full-length 61 expressed in $E$. coli has an $M_{\mathrm{r}}$ of 62000 , a size which fits well with that reported for 61 synthesized by transcription and translation in vitro (Forghani et al., 1990). In contrast, the protein expressed by VZV or VV61 is larger and has a heterogeneous $M_{\mathrm{r}}$ of $62 \mathrm{~K}$ to $65 \mathrm{~K}$. The difference in $M_{\mathrm{r}}$ between proteins expressed in prokaryotic and eukaryotic cells is due, at least largely, to phosphorylation at multiple sites, particularly in the amino-terminal region.

The protein is located in the nuclei of VZV- and VV61infected cells. It is present in the latter in a distinct punctate distribution, whereas in the former the pattern is more diffuse. Similar results have been reported for Vmw110, which gave punctate nuclear fluorescence when expressed by transfection of the Vmwl10 gene, but a more diffuse fluorescence when expressed in conjunction with Vmwl75 (Gelman \& Silverstein, 1986). When expressed by recombinant vaccinia viruses, $61 \mathrm{C}$ gives a non-punctate nuclear fluorescence, whereas $61 \mathrm{~N}$ remains in the cytoplasm. Therefore, sequences in the carboxy-terminal region of 61 are responsible for transport into or retention in the nucleus, and sequences in the amino-terminal region, which contains the potential zinc-binding domain, are required for punctate localization. The region responsible for nuclear localization of Vmwl10 expressed transiently is also located towards the carboxy terminus (Everett, 1988).

The similarities between 61 and Vmw110 are in accord with the view that the two proteins may share some functional properties. The role of $\mathrm{Vmw} 110$ as a transcriptional activator in HSV-1 infection has been investigated in detail (reviewed by Everett et al., 1991). It may act either on its own or in conjunction with Vmw175, the trans-activating ability of which it enhances significantly. Inchauspe et al. (1989) have found in transfection experiments that a plasmid containing VZV genes 
60 and 61 reduces expression of a marker gene (gene 36) from its basal level or from enhanced levels induced by the gene 62 and gene 4 proteins. Since there is no expectation or evidence that the HSV-1 counterpart of the gene 60 protein is involved in transcriptional regulation, these authors have suggested a potential role for 61 in repression of VZV transcription. In contrast, Cabirac et al. (1990) have found that 61 had no effect on expression of gene 36 or its HSV-1 counterpart, UL23, either alone or in conjunction with Vmw175 or the VZV gene 62 protein. These potentially conflicting results may be due to differences between experimental systems, particularly in the DNA fragments used as reporter promoters. More extensive investigations should resolve the confusion, and elucidate the functions of 61 in VZV infection.

Gene 61 is transcribed in VZV-infected cells to give a $1.8 \mathrm{~kb}$ RNA. This is consistent with the results of Reinhold et al. (1988), who have mapped an appropriately oriented $1.8 \mathrm{~kb}$ RNA to the region of the genome containing genes 59,60 and 61 by Northern blot analysis. Our transcript mapping data are consistent with initiation and polyadenylation of an unspliced mRNA of this size at the positions indicated in Fig. 1. Since, however, the Vmwllo mRNA is spliced, our data must be considered as preliminary because we have not systematically examined whether splicing occurs in transcription of gene 61. Nevertheless, we have noted in Fig. 1 that the proposed $5^{\prime}$ end of the mRNA maps about 25 bp downstream from an excellent candidate TATA element, which is downstream from two potential CAAT sequences.

The Vmwl10 gene possesses several upstream elements essential for immediate early expression, such as the TAATGARAT sequence (Mackem \& Roizman, 1982). We examined carefully the region upstream of gene 61 , but were unable to identify convincing examples of such elements. Thus, there is no indication from sequence data that gene 61 is an immediate early gene. Kinetic analysis of VZV gene expression is problematic because high titre cell-free virus of a satisfactory infectivity ratio cannot be prepared in cell culture. The two studies that have been carried out have identified different, but possibly overlapping, sets of immediate early proteins (Lopetegui et al., 1985; Shiraki \& Hyman, 1987). It is not clear whether any of these proteins correspond to 61 . The possibility that gene 61 is not an immediate early gene has precedents. The counterpart of gene 61 in a related herpesvirus, pseudorabies virus, is an early gene (Cheung, 1991), and transcription of the gene 61 homologue in equine herpesvirus 1 has not been detected under immediate early conditions (Gray et al., 1987; E. Telford, M. Watson, K. McBride \& A. Davison, unpublished data). In these respects pseudorabies virus and equine herpesvirus 1 , each of which has a single immediate early gene (that encoding the counterpart of Vmw175; Fenwick \& McMenamin, 1984; Gray et al., 1987), are likely to be better analogues of VZV than is HSV-1.

We are grateful to the Women of Scotland Luncheon, the Robertson Trust, the Hugh Fraser Foundation, and Mr and Mrs W. H. HampHamilton for financial support. We are particularly indebted to $\mathrm{Mr}$ and Mrs Hamp-Hamilton for their untiring interest in the work. We also thank Joan Macnab for establishing lines of contact with these sources, John Subak-Sharpe for his continued support and John McLauchlan for synthesizing the oligodeoxyribonucleotide.

\section{References}

Ackermann, M., Braun, D, K., Pereira, L. \& Roizman, B. (1984). Characterization of herpes simplex type 1 proteins 0,4 and 27 with monoclonal antibodies. Journal of Virology 52, 108-118.

AMman, E. \& Brosius, J. (1985). "ATG vectors" for regulated highlevel expression of cloned genes in Escherichia coli. Gene 40, 183-190.

Cabirac, G. F., Mahalingham, R., Wellish, M. \& Gilden, D. H. (1990). Trans-activation of viral tk promoters by proteins encoded by varicella-zoster virus open reading frames 61 and 62 . Virus Research $15,57-68$.

Cheung, A. K. (1991). Cloning the latency gene and the early protein 0 gene of pseudorabies virus. Journal of Virology 65, 5260-5271.

Chomczynski, P. \& SACCHI, N. (1987). Single-step method of RNA isolation by acid guanidinium thiocyanate-phenol-chloroform extraction. Analytical Biochemistry 162, 156-159.

Davison, A. J. \& Moss, B. (1989). Structure of vaccinia virus early promoters. Journal of Molecular Biology 210, 749-769.

DAvison, A. J. \& Moss, B. (1990). New vaccinia virus recombination plasmids incorporating a synthetic late promoter for high level expression of foreign proteins. Nucleic Acids Research 18, 4285-4286.

DAvison, A. J. \& ScoTT, J. E. (1983). Molecular cloning of the varicella-zoster virus genome and derivation of six restriction endonuclease maps. Journal of General Virology 64, 1811-1814.

DAVISON, A. J. \& SCOTT, J. E. (1985). DNA sequence of the major inverted repeat in the varicella-zoster virus genome. Journal of General Virology 66, 207-220.

Davison, A. J. \& SCOTT, J. E. (1986). The complete DNA sequence of varicella-zoster virus. Journal of General Virology 67, 1759-1816.

DISNEY, G. H. \& EvereTT, R. D. (1990). A herpes simplex virus type 1 recombinant with both copies of the Vmw175 coding sequences replaced by the homologous varicella-zoster virus open reading frame. Journal of General Virology 71, 2681-2689.

Dumas, A. M., Geelen, J. L. M. C., Weststrate, M. W., Wertheim, P. \& VAN Der NoORdaA, J. (1981). XbaI, Pst I and BgllI restriction endonuclease maps of the two orientations of the varicella-zoster virus genome. Journal of Virology 39, 390-400.

EVERETT, R. D. (1987). The regulation of transcription of viral and cellular genes by herpesvirus immediate-early gene products. Anticancer Research 7, 589-604.

EVERETT, R. D. (1988). Analysis of the functional domains of herpes simplex virus type 1 immediate-early polypeptide Vmw110. Journal of Molecular Biology 202, 87-96.

Everett, R. D., Preston, C. M. \& Stow, N. D. (1991). Functional and genetic analysis of the role of Vmw110 in herpes simplex virus replication. In Herpesvirus Transcription and its Regulation, pp. 49-76. Edited by E. K. Wagner. Boca Raton: CRC Press.

Felser, J. M., Kinchington, P. R., Inchauspe, G., Straus, S. E. \& Ostrove, J. M. (1988). Cell lines containing varicella-zoster virus open reading frame 62 and expressing the "IE" 175 protein complement ICP4 mutants of herpes simplex virus type 1. Journal of Virology 62, 2076-2082.

Fenwick, M. L. \& MCMENamin, M. (1984). Synthesis of $\alpha$ (immediateearly) proteins in Vero cells infected with pseudorabies virus. Journal of General Virology 65, 1449-1456. 
Forghani, B., Mahalingham, R., Vafai, A., Hurst, J. W. \& Dupuis, K. W. (1990). Monoclonal antibody to immediate early protein encoded by varicella-zoster virus gene 62. Virus Research 16, 195210.

Frame, M. C., Purves, F. C., McGeoch, D. J., Marsden, H. S. \& LEADER, D. P. (1987). Identification of the herpes simplex virus protein kinase as the product of viral gene US3. Journal of General Virology 68, 2699-2704.

Freemont, P. S., Hanson, I. M. \& Trowsdale, J. (1991). A novel cysteine-rich sequence motif. Cell 64, 483-484.

Gelman, I. H. \& Silverstein, S. (1986). Coordinate regulation of herpes simplex virus gene expression is mediated by the functional interaction of two immediate early gene products. Journal of Molecular Biology 191, 395-409.

Gray, W. L., Bauman, R. P., Robertson, A. T., Caughman, G. B., O'Callaghan, D. J. \& Staczek, J. (1987). Regulation of equine herpesvirus type 1 gene expression: characterization of immediate early, early and late transcription. Virology 158, 79-87.

InChaUSPE, G., NaGPaL, S. \& OStrove, J. M. (1989). Mapping of two varicella-zoster virus-encoded genes that activate the expression of viral early and late genes. Virology 173, 700-709.

Lopetegui, P., CAMPo-Vera, H. \& Yamanishi, K. (1985). Varicellazoster virus (VZV)-specific polypeptides detected in cells treated with metabolic inhibitors. Microbiology and Immunology 29, 569-575.

McGeoch, D. J., Dolan, A., Donald, S. \& Brauer, H. K. (1986). Complete DNA sequence of the short repeat region in the genome of herpes simplex virus type 1. Journal of Molecular Biology 181, 1-13.

McGeoch, D. J., Dalrymple, M. A., Davison, A. J., Dolan, A., Frame, M. C., McNab, D., Perry, L. J., Scott, J. E. \& Taylor, P. (1988). The complete DNA sequence of the long unique region in the genome of herpes simplex virus type 1. Journal of General Virology 69, 1531-1574.

MACKEM, S. \& RoIZMAN, B. (1982). Differentiation between $\alpha$ promoter and regulator regions of herpes simplex virus $1:$ the functional domains and significance of a movable regulator. Proceedings of the National Academy of Sciences, USA 79, 4917-4921.

Murphy, M., Schenk, P., Lankinen, H. M., Cross, A. M., Taylor, P., Owsianka, A., Hope, R. G., Ludwig, H. \& Marsden, H. S. (1989). Mapping of epitopes on the 65K DNA-binding protein of herpes simplex virus type 1. Journal of General Virology 70, 23572364.

Pereira, L., Wolff, M. H., Fenwick, M. L. \& Roizman, B. (1977). Regulation of herpesvirus macromolecular synthesis. V. Properties of polypeptides made in HSV-1 and HSV-2 infected cells. Virology 77, 733-749.

Perry, L. J., Rixon, F. J., Everett, R. D., Frame, M. C. \& MCGeOCH, D. J. (1986). Characterization of the IE110 gene of herpes simplex virus type 1. Journal of General Virology 67, 23652380.

PIETTE, J., KRYSZKE, M.-H. \& YANIV, M. (1985). Specific interaction of cellular factors with the B enhancer of polyoma virus. EMBO Journal 4, 2675-2685.

Preston, V. G., Davison, A. J., Marsden, H. S., Timbury, M. C., Subak-Sharpe, J. H. \& Wilkie, N. M. (1978). Recombinants between herpes simplex virus types 1 and 2: analyses of genome structures and expression of immediate early polypeptides. Journal of Virology 28, 499-517.

RANDALL, R. E. \& DiNwoodie, N. (1986). Intranuclear localization of herpes simplex virus immediate-early and delayed-early proteins: evidence that ICP 4 is associated with progeny virus DNA. Journal of General Virology 67, 2163-2177.

Reinhold, W. C., Straus, S. E. \& Ostrove, J. M. (1988) Directionality and further mapping of varicella-zoster virus transcripts. Virus Research 9, 249-261.

RÜTHER, U. \& MÜLLER-HILL, B. (1983). Easy identification of cDNA clones. EMBO Journal 2, 1791-1794.

Sambrook, J., Fritsch, E. F. \& Maniatis, T. (1989). Molecular Cloning: A Laboratory Manual, 2nd edn. New York: Cold Spring Harbor Laboratory.

SANDRI-GoldiN, R. M. (1991). Analysis of the regulatory activities of the HSV-1 $\alpha$ protein ICP27. In Herpesvirus Transcription and its Regulation, pp. 77-103. Edited by E. K. Wagner. Boca Raton: CRC Press.

Sears, A. E., Halliburton, I. W., Meignier, B., Silver, S. \& Rolzman, B. (1985). Herpes simplex virus 1 mutant deleted in the $\alpha 22$ gene: growth and gene expression in permissive and restrictive cells and establishment of latency in mice. Journal of Virology 55, 338-346.

ShIRAKI, K. \& Hyman, R. W. (1987). The immediate early proteins of varicella-zoster virus. Virology 156, 423-426.

Smith, C. L., Debouck, C., Rosenberg, M. \& Culp, J. S. (1989). Phosphorylation of serine residue 89 of human adenovirus E1A proteins is responsible for their characteristic electrophoretic mobility shifts, and its mutation affects biological function. Journal of Virology 63, 1569-1577.

Steers, E., Cuatrecasas, P. \& Pollard, H. P. (1971). The purification of $\beta$-galactosidase from Escherichia coli by affinity chromatography. Journal of Biological Chemistry 246, 196-200.

Srow, N. D. \& Srow, E. C. (1986). Isolation and characterization of a herpes simplex virus type 1 mutant containing a deletion within the gene encoding the immediate-early polypeptide Vmw110. Journal of General Virology 67, 2571-2585.

(Received 14 August 1991; Accepted 6 November 199I) 